\title{
Temperature and Irradiance Influence Growth and Development of Three Cultivars of Achimenes
}

\author{
J.C. Vlahos ${ }^{1}$ \\ Department of Horticulture, Agricultural University, P.O. Box 30, 6700 \\ AA Wageningen, The Netherlands
}

Additional index words. flowering, light duration, rhizomes

\begin{abstract}
Three cultivars of Achimenes, 'Flamenco', 'Hilda', and 'Rosenelfe', were grown for 10 weeks in nine environments: 17, 21, and $25 \mathrm{C}$ combined with 8,16 , or 24 hours of irradiance $\left(213 \mu \mathrm{mol} \cdot \mathrm{s}^{-1} \cdot \mathrm{m}^{-2}\right)$. Increase in temperature increased plant height, number of nodes, number of flowers, and shortened time to anthesis. Number of axillary shoots was enhanced at 17C. Increasing duration of illumination increased shoot dry weight and reduced plant height; a 16-hour light duration compared to 8 or 24 hours increased size and fresh and dry weight of rhizomes. 'Rosenelfe' responded differently from 'Flamenco' and 'Hilda' to the environmental treatments. Depending on cultivar, top growth and flowering were influenced by temperature and duration of illumination, whereas rhizome growth was affected mainly by the latter.
\end{abstract}

Although the genus Achimenes and its hybrids have been known and grown for a long time, it is only recently that they have become popular as commercially grown potted plants in the United States and Europe (Jungbauer, 1977; Moore, 1957). Rohde (1974) using 'Valse Bleu' and 'Domröschen' showed that they are day-neutral plants, that flower development was faster at 20C than at lower or higher temperatures, and that the number of flowers depended on the number of nodes produced. Deutch (1974) indicated that rhizome formation in cuttings of 'Major' is inhibited by continuous illumination, while Zimmer (1976) working with four cultivars, reported that the number of rhizomes was not affected by short (8-hr) or long (16-hr) days. The purpose of the present study was to investigate the influence of temperature and irradiance on flowering, rhizome formation, and vegetative development of achimenes plants grown under controlled conditions. The effect of daylength is reported in a companion report (Vlahos, 1990).

The commercial cultivars Flamenco, Hilda Michelssen (referred 10 as 'Hilda') and Rosenelfe were used. Young plants of the three cultivars, started from rhizomes, were obtained from a commercial grower in Apr. 1985. Rooted stem cuttings of uniform length were selected, potted in $10-\mathrm{cm}$ (0.3-liter) plastic pots and placed in a greenhouse with natural daylength at $\approx 21 \mathrm{C}$ for 2 weeks be-

Received for publication 28 July 1989. Publication no. 567, Dept. of Horticulture, Agricultural University Wageningen, The Netherlands. The author acknowledges support of a research fellowship from the State Scholarships Foundation of Greece. The cost of publishing this paper was defrayed in pan by the payment of page charges. Under postal regulations, this paper therefore must be hereby marked advertisement solely to indicate this fact.

${ }^{1}$ Associate Professor of Botany. Current address: Dept. of Horticulture, Technological Educational Institute, Iraklion, 71500 Crete, Greece. fore the start of the experimental treatments. AI that time, the plantlets averaged 3 to 4 $\mathrm{cm}$ in height and had $\approx 4$ nodes (leaf whorls). No flower buds were visible; only axillary shoots had emerged from the lower leaf axils.

The plants were placed at 17,21 , or $25 \mathrm{C}$ (constant day/night) combined with 8,16 , and $24 \mathrm{hr}$ of irradiance, thus providing nine experimental conditions. The level of irradiance in each light treatment was a constant $213 \mu \mathrm{mol} \cdot \mathrm{s}^{-1} \cdot \mathrm{m}^{-2}$ at plant level. Illumination was provided by a combination $(1: 1)$ of high-pressure sodium (Philips SON/T) and metal halide (Philips HPI/T) lamps of 250 or $400 \mathrm{~W}$. A split-plot design was set up with three temperatures (main plots), three illumination periods (subplots), and three cultivars randomized in each subplot. There were two replications per light treatment with four plants in each replication. The experiment involved a total of 216 plants.

The number of days until the first flower opened was recorded for each plant. AI the end of the experiment, the following data were collected: height of the main stem, number of axillary shoots, total number of flowers, shoot fresh and dry weights. Rhizomes were harvested, counted, and their fresh and dry weights were recorded. The ratio of rhizome dry weight to total dry weight (aerial parts and rhizomes) was calculated and is referred to as the rhizome weight ratio (RWR). The mean dry weight of rhizomes was divided by the number of rhizomes to obtain the dry weight per rhizome as an estimate of their size. Finally, the plants were evaluated for general quality and for flower appearance and color.

The results of the experiment were subjected to analysis of variance. From the $\mathrm{F}$ tests it appeared that means of cultivars, light and temperature treatments. and interactions of cultivar with treatments for all characteristics measured were significantly different $(P<0.001)$. Means were separated by least significant difference at $\mathrm{P}=0.05$. The confounding of the temperature effect with the chamber effect was taken into consideration. Interactions between temperature and light treatments were nonsignificant for all characteristics studied.

Temperature interacted with cultivar for stem height, number of nodes, number of flowers, and days to anthesis (Table 1). In 'Flamenco' and 'Hilda', plant height and number of flowers were lower at $17 \mathrm{C}$ than at 21 or $25 \mathrm{C}$; in 'Rosenelfe', these values were highest at $21 \mathrm{C}$. Number of flowers in all cultivars was correlated to stem height $(r$ $=0.81)$ and number of nodes $(r=0.74)$. In 'Hilda', the number of days to first open flower decreased as temperature increased, whereas in 'Flamenco' and 'Rosenelfe' the difference between 21 and $25 \mathrm{C}$ was not significant. No interactions were evident for number of axillary shoots, number of rhizomes, or rhizome dry weight (Table 2). Number of axillary shoots decreased as temperature increased; at $21 \mathrm{C}$ number of rhizomes was lowest, whereas dry weight per rhizome was highest.

As light duration increased, height of the main stem decreased: number of flowers was not affected in 'Flamenco', whereas for 'Hilda' most flowers developed at $24 \mathrm{hr}$ for 'Rosenelfe' at $16 \mathrm{hr}$ (Table 3). There was no interaction with either cultivar or temperature treatment for tissue weights (Table 4). Dry weight of shoots was higher at 16 and $24 \mathrm{hr}$ than at $8 \mathrm{hr}$; the dry weights of rhizomes and per rhizome were higher at $16 \mathrm{hr}$ than at 8 or $24 \mathrm{hr}$.

There were significant differences among the three cultivars in several characteristics of their growth and development under any of the treatments (Table 5). In 'Flamenco', shoot dry weight was lowest, whereas dry weights of rhizomes and per rhizome and RWR were the highest among the cultivars. In 'Hilda', the number of rhizome, dry weight of rhizomes, and RWR were the lowest among the three cultivars. 'Rosenelfe' had more axillary shoots than the others; also flower number was correlated with axillary shoots $(r=0.83)$. Shoot dry weight and the number of rhizomes were higher for 'Rosenelfe' than for 'Flamenco' or 'Hilda'.

Plants of all cultivars, under any of the temperature treatments, were vigorous and had dark green foliage at $8 \mathrm{hr}$ of light; at 16 $\mathrm{hr}$, the leaves were a lighter green and plants were more compact. At $24 \mathrm{hr}$, however, leaves became chlorotic and growth of plants was stunted with evident characteristics of senescence. Furthermore, the color of the flowers changed noticeably in relation to temperature. The higher the temperature, the paler the color of the corolla. At $24 \mathrm{hr}$ of light and $25 \mathrm{C}$, flower color had changed to a very light shade of red (in 'Flamenco' and 'Rosenelfe') or pink (in 'Hilda').

Vegetative and reproductive development in achimenes, as shown by increase in height and number of flowers, are affected by temperature. However, this effect depends on the cultivar (Table 1). It has been shown that several species flower earlier as temperature 
Table 1. Interaction of temperature with cultivar on growth and flowering in Achimenes ${ }^{\mathrm{z}}$.

\begin{tabular}{|c|c|c|c|c|c|c|c|c|c|c|c|c|}
\hline \multirow[b]{3}{*}{ Cultivar } & \multicolumn{3}{|c|}{$\begin{array}{l}\mathrm{Ht} \text { of main } \\
\text { stem }(\mathrm{cm})\end{array}$} & \multicolumn{3}{|c|}{ Nodes (no.) } & \multicolumn{3}{|c|}{ Flowers (no.) } & \multicolumn{3}{|c|}{$\begin{array}{c}\text { Days to } \\
\text { first flower } \\
\text { (no.) }\end{array}$} \\
\hline & \multicolumn{12}{|c|}{ Temperature $\left({ }^{\circ} \mathrm{C}\right)$} \\
\hline & 17 & 21 & 25 & 17 & 21 & 25 & 17 & 21 & 25 & 17 & 21 & 25 \\
\hline Flamenco & $14.5 \mathrm{a}$ & $16.6 b c$ & $16.5 \mathrm{bc}$ & $7.4 \mathrm{a}$ & $8.7 b$ & $10.0 c$ & 11.03 & $15.7 b$ & $16.6 b$ & $22 \mathrm{~b}$ & $9 a$ & $8 a$ \\
\hline Hilda & $15.6 \mathrm{a}$ & $17.2 \mathrm{c}$ & $16.7 \mathrm{bc}$ & $9.0 \mathrm{~b}$ & 9.5 bc & $11.4 \mathrm{~d}$ & $12.8 \mathrm{ab}$ & $21.7 \mathrm{c}$ & $23.0 \mathrm{c}$ & $29 \mathrm{c}$ & $19 \mathrm{~b}$ & $11 \mathrm{a}$ \\
\hline Rosenclfe & $22.8 d$ & $24.7 \mathrm{e}$ & $22.0 \mathrm{~d}$ & $10.4 d$ & $11.3 \mathrm{c}$ & $10.6 \mathrm{de}$ & $62.1 \mathrm{~d}$ & $78.3 \mathrm{e}$ & $66.4 d$ & $18 \mathrm{~b}$ & $12 \mathrm{a}$ & $9 \mathrm{a}$ \\
\hline
\end{tabular}

${ }^{\mathrm{z}}$ Mean separation within each characteristic by LSD at $P=0.05$. Values are means of 24 plants averaged over three irradiance treatments.

Table 2. Main effect of temperature on axillary shoot and rhizome development in Achimenes. ${ }^{z}$

\begin{tabular}{lccc}
\hline $\begin{array}{l}\text { Temperature } \\
\left({ }^{\circ} \mathrm{C}\right)\end{array}$ & $\begin{array}{c}\text { Axillary } \\
\text { shoots (no.) }\end{array}$ & $\begin{array}{c}\text { Rhizomes } \\
(\text { no. })\end{array}$ & $\begin{array}{c}\text { Dry withizome } \\
(\mathrm{mg})\end{array}$ \\
\hline 17 & $3.2 \mathrm{c}$ & $4.8 \mathrm{~b}$ & $66.5 \mathrm{a}$ \\
21 & $2.8 \mathrm{~b}$ & $3.2 \mathrm{a}$ & $109.0 \mathrm{~b}$ \\
25 & $2.4 \mathrm{a}$ & $4.2 \mathrm{~b}$ & $82.2 \mathrm{a}$ \\
\hline
\end{tabular}

${ }^{\mathrm{z}}$ Mean separation within columns by LSD at $P=0.05$. Values are means of 72 plants averaged over three cultivars and three irradianccs.

Table 3. The effect of light duration on height and number of flowers in three cultivars of Achimenes ${ }^{\mathrm{z}, \mathrm{y}}$.

\begin{tabular}{|c|c|c|c|c|c|c|}
\hline \multirow[b]{3}{*}{ Cultivar } & \multicolumn{3}{|c|}{$\begin{array}{l}\text { Hi of main } \\
\text { stcm }(\mathrm{cm})\end{array}$} & \multicolumn{3}{|c|}{ Flowers (no.) } \\
\hline & \multicolumn{3}{|c|}{ Hours of irradiance } & \multicolumn{3}{|c|}{ Hours of irradiance } \\
\hline & 8 & 16 & 24 & 8 & 16 & 24 \\
\hline Flamenco & $17.9 \mathrm{c}$ & $15.0 \mathrm{ab}$ & $14.7 \mathrm{a}$ & $13.9 \mathrm{a}$ & $14.6 \mathrm{a}$ & $14.7 \mathrm{a}$ \\
\hline Hilda & $19.1 \mathrm{~cd}$ & $16.2 b$ & $14.3 \mathrm{a}$ & $16.9 \mathrm{a}$ & $18.5 \mathrm{ab}$ & $22.0 \mathrm{~b}$ \\
\hline Rosenclfe & $26.7 \mathrm{f}$ & $22.5 \mathrm{e}$ & $20.3 d$ & $65.0 \mathrm{c}$ & $74.3 \mathrm{~d}$ & $67.4 c$ \\
\hline
\end{tabular}

Constant irradiance level of $213 \mu \mathrm{mol} \cdot \mathrm{s}^{-1} \cdot \mathrm{m}^{-2}$.

${ }^{\mathrm{y}}$ Mean separation within each characteristic by LSD at $P=0.05$. Values arc means of 24 plants averaged over three temperatures.
Table 4. Main effect of light duration on shoot and rhizome dry weight in Achimenes ${ }^{z, y}$.

\begin{tabular}{lccc}
\hline \hline $\begin{array}{l}\text { Duration } \\
\text { of } \\
\text { irradiance } \\
\text { (hr) }\end{array}$ & \multicolumn{3}{c}{ Drw wl (g) } \\
\cline { 2 - 4 } & Shoots & Rhizomes & Per rhizome \\
\hline 8 & $1.5 \mathrm{a}$ & $0.26 \mathrm{a}$ & $0.063 \mathrm{a}$ \\
16 & $2.1 \mathrm{~b}$ & $0.47 \mathrm{~b}$ & $0.114 \mathrm{~b}$ \\
24 & $2.3 \mathrm{~b}$ & $0.27 \mathrm{a}$ & $0.078 \mathrm{a}$ \\
\hline
\end{tabular}

${ }^{\mathrm{z}}$ Constant irradiance level of $213 \mu \mathrm{mol} \cdot \mathrm{s}^{-1} \cdot \mathrm{m}^{-2}$.

${ }^{\mathrm{y}}$ Mean scparation within columns by LSD at $P=$ 0.05 . Values are means of 72 plants averaged over three cultivars and three temperatures.

increases (Djurhuus, 1985; Maginess and Langhans, 1961; Piringer and Cathey, 1960; Rohde, 1974); the present results agree with these reports.

The number of axillary shoots was highest at $17 \mathrm{C}$, as higher temperatures favored initiation of flowers instead of shoots. Relatively higher temperatures reportedly inhibit tuberization in potato (Menzel, 1983); in the

present studies, where rhizome formation and development were related to tuberization, no such evidence was found. Weight of rhizomes and RWR were not significantly affected by temperature; differences existed only among cultivars. However, at 21C, dry weight per rhizome increased as a result of fewer rhizomes being formed (Table 2).

The effect of light treatment on plant height and number of flowers varied with the cultivar (Table 3). It is uncertain whether these effects are due to the duration of the irradiance period or to the amount of total energy provided at plant level, as the amount of radiant energy varied proportionately with daylength. Although morphogenetic effects due to the extended light period cannot be excluded, it is possible that the responses obtained are attributable to genetic factors, as cultivars differ in several growth characteristics (Table 5).

The enhanced rhizome weight at $16 \mathrm{hr}$ suggests an optimal amount of light energy for rhizome development (Table 4); the

Table 5. Main characteristics of three cultivars of Achimenes ${ }^{z}$.

\begin{tabular}{lccc}
\hline \hline & & & \\
Characteristic & Flamenco & Hilda & Rosenelfe \\
\hline Axillary shoots (no.) & $1.6 \mathrm{a}$ & $1.9 \mathrm{a}$ & $4.9 \mathrm{~b}$ \\
Dry wt of shoots $(\mathrm{g})$ & $1.3 \mathrm{a}$ & $2.0 \mathrm{~b}$ & $2.5 \mathrm{c}$ \\
Dry wt of rhizomes $(\mathrm{g})$ & $0.52 \mathrm{c}$ & $0.15 \mathrm{a}$ & $0.33 \mathrm{~b}$ \\
Dry wt per rhizome $(\mathrm{mg})$ & $120 \mathrm{~b}$ & $74 \mathrm{a}$ & $63 \mathrm{a}$ \\
Rhizomes (no.) & $4.3 \mathrm{~b}$ & $2.1 \mathrm{a}$ & $5.8 \mathrm{c}$ \\
Rhizome weight ratio (RWR) & $27.4 \mathrm{~b}$ & $7.2 \mathrm{a}$ & $12.4 \mathrm{c}$ \\
\hline
\end{tabular}

${ }^{\mathrm{z}}$ Mean separation within rows by LSD at $P=0.05$. Values are means of 72 plants averaged over three irradiances and three temperatures. number of rhizomes was not affected by the light treatment. The present results are contrary to those of Deutch (1974), who found that continuous light inhibited rhizome formation, but are in agreement with those of Zimmer (1976), who reported that daylength does not influence the number of rhizomes. However, cultivars and quantities of light energy in the present experiment were different from those in the other studies. The best rhizome development and the highest RWR values were observed in 'Flamenco', signs of strong sink activity of the stolons in this cultivar. 'Rosenelfe' produced more flowers as a result not only of the increased number of axillary shoots, but also because of the many-flowered peduncles that characterize the cultivar.

The present study demonstrates that both temperature and quantity of radiant energy influence growth and development in achimenes, but responses may vary, depending on the cultivar.

\section{Literature Cited}

Deutch, B. 1974. Bulblet formation in Achimenes longiflora. Physiol. Plant. 30:113-118.

Djurhuus, R. 1985. The effect of photoperiod and temperature on growth and development of $\mathrm{Be}$ gonia x ruberhybrida 'Karelsk Jomfru' Scientia Hon. 27:123-131.

Jungbauer, J. 1977. Eine wunderschöne Pflanze die Keiner kultivieren will. Gb + Gw (Gärtnerbörse-Gartenwelt) 26:604-606.

Maginess, E.A. and R.W. Langhans. 1961. The effect of photoperiod and temperature on initiation and flowering of snap dragon (Anthirrhinum majus var. Jackpot). J. Amer. Soc. Hort. Sci. 77:600-607.

Menzel, J.C.M. 1983. Tuberization in potato at high temperatures: interaction between root and shoot temperatures. Ann. Bot. 52:65-69.

Moore, H.E. Jr. 1957. Gesneriads with scaly rhizomes. African violets, gloxinias, and their relatives. A guide IO the cultivated Gesneriads. Macmillan. New York. p. 98-113.

Piringer, A.A. and H.M. Cathey. 1960. Effect of photoperiod, kind of supplemental light and temperature on the growth and flowering of Petunia plants. J. Amer. Soc. Hort. Sci. 76:649660.

Rohde. J. 1974. Einfluss der Tageslänge und Temperatur auf die Trieb- und Blütenbildung der Achimenes Hybriden 'Valse Bleu' und 'Domröschen'. Gartenbauwissenschaft 32:135150.

Vlahos, J.C. 1990. Daylength influences growth and development of Achimenes cultivars. HortScience 25:1595-1596.

Zimmer, K. 1976. Bildung and Lagerung von Achimenes Rhizomen. Deutscher Gartenbau 6:179-180. 